\title{
Corporate Social Responsibility and Corporate Communication
}

\author{
Poppy Ruliana \\ Head of the Agency for Social Care and Research \\ STIKOM InterStudi \\ Jakarta, Indonesia \\ Poppyruliana30@gmail.com
}

\begin{abstract}
The purpose of this paper is a study on the idea that organizations are aware of the importance of the stakeholders objectives especially in improving profits for the company's business through corporate image and reputation. The important factor to boost the image and reputation is through the ability to communicate, and to innovate the human resources, and to build the company's performance. In short, communication can connect internal and external interests of the public, especially for carrying out Corporate Social Responsibility (CSR) programs. Therefore, it is important to analyze theoretically as well as looking in practice on how the relationship between CSR and Communication of a corporation can improve the business image and reputation.
\end{abstract}

Keywords- CSR, Communication and Corporate Communication

\section{INTRODUCTION}

Public Relations is the forerunner of the Corporate Communication function. Despite some corporations do not have a specific strategy for their communication system, they have often to response to their internal and external publics. Following the above understanding, any form of communication holds an important function. In Corporate Social Responsibility (CSR) those three elements (vision, mission and values) should interact and support each other. With an active participative communication among the stakeholders, the decision making, the executing of the decision and the implementing of the CSR responsibility itself will be kept together. However, in perspective of looking to the future of CSR. In other words, the corporation. Therefore, the further development of CSR is following the concept of sustainability development.

The sustainability principle sets affront the development, especially to the poor community in managing its surroundings with the ability of the institution conducting the program. The institution's strategic program should integrate the economic, ecology and social dimension, also to respect the pluralism of the ecological and social-cultural aspects. That is why when concerning CSR then it also matters with Public Relations, as Public Relations is part of community relations.

Since CSR is a Public Relations activity, the steps in conducting of a CSR program is such as conducting a Public Relations process. Communication in CSR is a responsibility form from the corporation to all its stakeholders in telling its idea, suggestion, as well as critics and adaptive responses.

\author{
Marlinda Irwanti \\ Chairman of the Department of Public Relations \\ STIKOM InterStudi
}

[1] stated that when a corporation is conducting a CSR program continuously and as an on-going activity, becomes one of the means in preventing crisis to happen through building corporate image and reputation. It is to remind that CSR is not a program that conducted periodically just following the trend and not by planning. CSR can prevent a crisis to happen if the program is sustainable and building a long-term relationship with the community. The relevancy of social responsibility against corporate communication.

\section{RESEARCH METHOD}

To understand and to analyze the relevancy of corporate social responsibility against corporate communication. Various data compiled are qualitative as the research is a literature study. Although others approach differently, similar naming have its similarities, some even identical to CSR among others are: Corporate Social Investment/Investing, Corporate Giving, and Corporate Philanthropy. By theory, when talking about responsibility which should be extended by a corporation; at least two meanings should be understood: the morale or the ethical responsibility, and the liability responsibility as a legal responsibility.

\section{RESULT FINDINGS AND DISCUSSION}

In a general the understanding of CSR consist of three main items which are: firstly that CSR is voluntary wherein a corporation is helping solving social and community problems, therefore the corporation has the free will to act or not. Secondly aside as a profit institution the corporation will set aside a part of its profit for philanthropy with the objective for social enforcement and maintenance of the environment damage due to the exploration and exploitation. Thirdly CSR as a corporate obligation to caring and elevating the human crisis and its surroundings which keeps mounting.

The CSR concept came along when the DEAF phenomenon arose among the industrialized society, an acronym of: De-humanism, Equalization, Aquariumization, and Femininezation [2]. De-humanism industry, efficiency and mechanism which becomes strongerin the industrial world created problem to humans, whether it happens among laborers as well as problems to the community living near the industry sites. Equalization of public liabilities, the society are becoming more aware of their liabilities and demanding the corporation responsibility on different kinds of social problems that often arises as a result of the corporation's operation. Aquariumization of the world industry, the workers' world becomes more transparent and open like an aquarium. Femininezation of the work force., since more women are in the work force, not only internal 
demand arises, such as allowing of pregnancy and birth leave, health and safety working conditions, as well as the appearances of social costs, such as child care avoidance, teen-agers delinquency, due to the shortening presence of the mothers at home and in the society.

The understanding of CSR is also based on the thinking that not only the government through its public policy is responsible for the social problems, but the corporation must also take responsibility. CSR forms also develops from that as charity principle to stewardship principle [3]. Based on charity principle, society have the morale obligation to giving support to the less fortunate. Such a corporate support is needed and important especially where the government has no social guarantee system, health care to elderly and financial aid for the un-employed.

Types of CSR programs can be classified as Community Development (CD); and as Relations Development (RD). The objectives of the CSR programs (CD \& RD) are: The enforcement of the local human resources (students and youngsters are included); The enforcement of the socal economy surrounding the operational locations; The development of general/community facilities; The development of public health; Other social-cultural development. CSR programs can be in the form of labor recruitment by employing the surrounding community. A CSR program can also be in the form of building a pleasant working environment amongst the workers; especially when the labors can be involved in activities which they believe will bring benefits to the broader community whether in saving a part of their salary, financial collection or volunteering working for the community.

CSR programs can be in the form of labor recruitment by employing the surrounding community. A CSR program can also be in the form of building a pleasant working environment amongst the workers; especially when the labors can be involved in activities which they believe will bring benefits to the broader community whether in saving a part of their salary, financial collection or volunteering working for the community. However, worth to be noted that CSR programs are not only community programs which can make the corporate as a charity body or even as part of the government's social department. The benefits of corporate social responsibility to the corporation are among others: Building reputation, Building corporate image, Strengthening corporate brand, Developing corporative activities with stakeholders, Differencing the corporation from its competitor, Producing innovation and learning in building corporate influences, Opening the access for investing and paying costs for the corporation, Elevating share price.

The Success of CSR programs within the company is very much determined by the selection of the right issues in the focus of its activities. The selection of such issues need to take into consideration a number of data, or taking on the issues that are often discussed, then adjust it to the needs of the stakeholders. Thus, the issue of CSR programs are selected must support and provide a good position for the company.

The selection of an interesting CSR issue contains issues that are often discussed which will be able to invite the media to help to communicate the CSR program to all stakeholders. After conducting the company's CSR activities, the next step is that the company communicate the CSR programs. The aim of the communication of the activity is as a form of corporate accountability to all stakeholders related to the CSR activities which are being conducted. Things like this can also encourage other companies to conduct CSR activities.

The implementation of the program through the activities of the company policy of corporate responsibility or corporate social responsibility, as well as the implementation of CSR programs undertaken by one of the State-Owned Enterprises in Indonesia, namely the digital SME (small and medium enterprises) "kampong programs" (commrezaon people houses program) that had been implemented since June 2015, as a form of Corporate Social Responsibility (CSR) to help Indonesia in the framework of the modernization of SMEs and improving the competence of SMEs through Information Communication Technology (ICT). Telkom (the telecommunication state-owned company) had built the Digital SMEs with the help of a number of Telkom's products such as Jarvis, BosToko, Blanja, and the Directory of SME Smart Business. The main goal of the program is how to help the SME for not only selling in the market or through traditional distribution, but also penetrating the broader market although with limited knowledge of digital technology products.

In relation to supporting SMEs, Telkom has pioneered since three years ago, and now is the time to digitalized the SMEs and the "kampong". Digitalized means that all businesses activities are carried out by SMEs become easily accessible. Assistant to the economy of South Jakarta Shita Damayanti said the program is a program of the provincial Government of DKI Jakarta, with its smart city that all services are already online. She stated that entering the era of the ASEAN Economic Community, one of the programs that can promote the SMEs is conducting the "Kampong Digital". As the Government of South Jakarta has already cooperating with shopping malls by letting the vendors and SMEs doing businesses in the malls.

The implementation of CSR Telkom if linked to the process of Public Relations. First conducted by Telkom is the fact finding process or fact finding in advance to identify problems that occur in an environment of SMEs in various forms of the type of business carried out by entrepreneurs and SMEs that may encounter difficulties in marketing their products due to the limitations of the media to promote its products. The main goal of the program is how to help the SMEs not only selling in the market or through traditional distribution, but also penetrating the broader market although with limited knowledge inthe digital technology.

The impact is not only to companies, but such activities constitute a campaign program is intended for businesses and communities. Before communicating the CSR programs, the company should understand about the communication models. In communicating the CSR programs, businesses need to consider the selection of communication media which will be used. Before selecting the relevant media, there are a few things to consider (Reza Rahman, page 74), among other things: Characteristics of the stakeholders that will be the target of the communication, The selection of media is based on its 
credibility and character, Time management delivery of a message to the receiver, The number of available communication budget.

The strengths and weaknesses of various communication media can be outlined as follows: Television, Radio, Newspaper, Magazine, Internet. With regards to the communication of CSR committed by companies to improve its image, the company must select the CSR issues which should be interesting and could strengthen the company's reputation. This issue can be obtained from communication that is indeed designed programmatically by the company, and is packed in an interesting form. One of the CSR activities for example, were derived from the activity of the community development which then can be communicated to the stakeholders.

The development of CSR and corporate communication is the process of convergence where both thoughts are started from different points, but in a variety of things can be said to be similar, as follows: CSR and corporate communication and internal-oriented rather than closed, instead of CSR and corporate communication is the process of yangg open and oriented to all stakeholders, CSR and corporate communication should not be internally oriented, and not be inside closed doors. CSR and corporate communication is a management function which demands the involvement of various parties in the organization structure. CSR and corporate communication activities are not isolated but rather are a mutual activity presupposes and synergistically contribute to the development and sustainability of the company.

Specifically the interaction between CSR and corporate communication can be described as shown below:

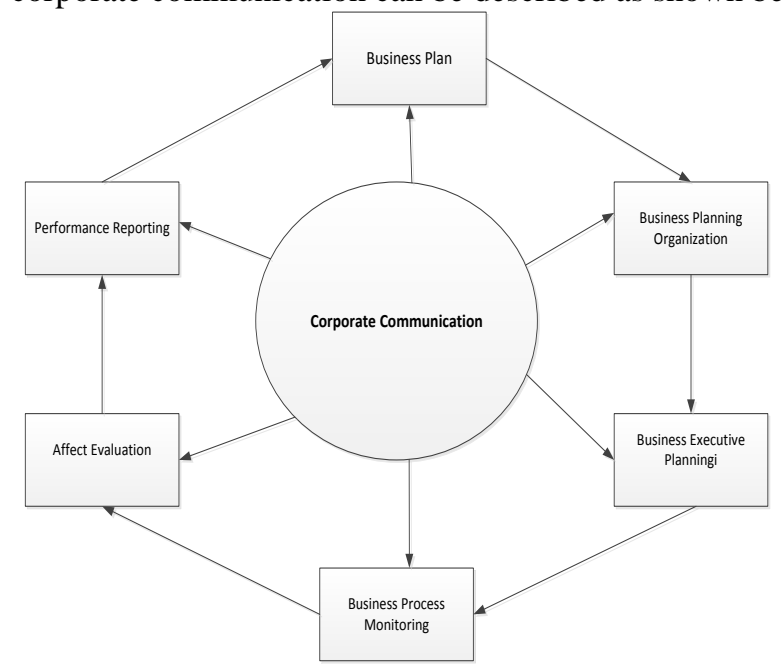

So that communication can run effectively, a Communicator or PR officer need to understand about The Inevitable Laws of the 5 Efffective Communication Law, which can be conceived as a communication strategy in putting together an effective communication: Respect, Empathy, Audible, Clarity, Humble.

If we build communication based on the five laws of effective communication, then we will be able to become a reliable communicators. We will in turn establish or build a network of relationships with others that is meaningful and creating mutual understanding because we positioned as a full trusted communicator (source of credibelity). Like a wise we become a source of attractiveness because it can create things that make the receiver or public, noticing the messages we convey.

These all are depending on timing, the language, attitudes and values which must be shown to be effectivefor certain groupsto whom the communication will be executed to. It is important to pay attention to the following: There are similarities between the communicator and message's receiver in the frames of reference and the field of experience, Having common ideology is stronger than being in common demographic, Communicators must be able to equate itself with the target receiver so that there arose sympathy.

\section{CONCLUSION}

The success in communicating the CSR programs are defined by revealing the issues packed interestingly send out by appropriate communication media. The selection of an appropriate communication media $s$ the means to communicate the CSR program through counting on its strength and weaknesses, plus its support with the corporation budget. A CSR program has the positive ability to elevate the company's image when the activities are executed continuously, quantitatively well managed, upon an internal as well as external orientation. CSR programs executed continuously is one of the means to prevent a crisis to happen by elevating the corporate image in view of its stakeholders.

\section{REFERENCES}

[1] Rahman, Reza. 2009. Corporate Social Responsibility, Antara Teori dan Kenyataan. (Corporate Social Responsibility, Between Theory and Facts) Jakarta: MedPress.

[2] Suharto, Edi, 2007, Pekerjaan Sosial di Dunia Industri: Memperkuat Tanggungjawab Sosial Perusahaan. (Social Works in the Industrial World: Strengthening the Social Responsibility of Corporations), Bandung : Refika Aditama.

[3] Anne, L. T. (2005). Business and Society: Stake Holders, Ethics, Public Policy (International, 11 ed.): Mc Graw Hill. Indonesian. 